Bioscientia Medicina: Journal of Biomedicine \& Translational Research

Journal Homepage: www.bioscmed.com

\title{
Analysis of Neuron Specific Enolase Serum Levels in Traumatic Brain Injury
}

\section{Yuliarni Syafrita ${ }^{1^{*}}$, Nora Fitri ${ }^{2}$}

${ }^{1}$ Neurology Staff, Faculty of Medicine, Andalas University/Dr. M Djamil Hospital, Padang, Indonesia

2Resident of Neurology, Faculty of Medicine, Andalas University/Dr. M Djamil Hospital, Padang, Indonesia

\section{A R T I C L E I N F O}

\section{Keywords:}

Brain injury

Glasgow outcome scale

Neuron specific enolase

\section{*Corresponding author:}

Yuliarni Syafrita

\section{E-mail address: syafrita.yuliarni@gmail.com}

All authors have reviewed and approved the final version of the manuscript.

https://doi.org/10.32539/bsm.v5i4.413

\begin{abstract}
A B S T R A C T
Background: Traumatic brain injury is still the main cause of death and disability in productive age. Assessment the level of consciousness and imaging examinations after a brain injury can not always describe the severity of damage in the brain, this is because the pathological process is still ongoing due to secondary brain injury. Therefore, it is necessary to examine biomarkers that can describe the severity of the pathological process that occurs. The purpose of this study was to assess serum neuron-specific enolase (NSE) levels and their relationship to the severity and outcome of a traumatic brain injury. Methods: A cross sectional design was conducted in the emergency department of DR M Djamil Hospital, Padang. There were 72 patients who met the inclusion criteria. A Glasgow Coma Scale examination was performed to assess the severity of brain injury and examination of NSE serum levels at 48 hours post- injury using ELISA technique and assess the Glasgow outcome scale (GOS) at 6 weeks post-injury. Data analysis using SPSS 22 program, the results are significance if the $p$ value $<0.05$ Results: The average NSE level was higher in severe brain injuries than moderate and mild brain injuries and this difference was statistically significant $(p<0.05)$. The NSE serum levels were higher in poor outcomes than in good outcomes and this difference was statistically significant $(p<0.05)$. Conclusion: High NSE serum levels in the acute phase were associated with the severity of the brain injury and poor outcome 6 weeks after the brain injury.
\end{abstract}

\section{Introduction}

Traumatic brain injury is still a major cause of mortality and morbidity worldwide. The incidence reaches 10 million cases per year in the world, although there is a decrease in the death rate, the post traumatic brain injury disability rate is still worrying, especially with changing demographic patterns, where the victims affected young age and older.1,2,3

Several examinations, such as an assessment of the level of consciousness during a brain injury and imaging examinations, which are often performed when the patient arrives at the hospital, cannot always describe the damage severity in the brain. This is due to the ongoing series of secondary injuries that follow the primary injury. 4,5,6 Therefore, early imaging is not always able to predict the outcome of a brain injury.

Therefore, the examination of biomarker levels in serum hopefully can describe ongoing pathological conditions. Several biomarkers that only present in the brain can be found in cerebrospinal fluid and serum due to impaired of the blood-brain barrier. One of these biomarkers is neuron specific enolase (NSE).7,8

Neuron specific enolase (NSE) is an enzyme involved in the glycolysis of nerve cells and specific for the brain. Several reports have found elevated serum levels of NSE correlated with unfavorable outcomes ${ }^{9}$. Based on the above background, the researcher wanted to know the relationship between serum NSE levels 48 hours after traumatic brain injury with severity and outcome.

\section{Methods}

Study with a cross-sectional design was carried out on patients with traumatic brain injuries at the Emergency Department of Dr. M Djamil Hospital, 
Padang during March - July 2021. There were 72 patients who met the inclusion criteria, there are aged 18-60 years, with onset of 24-48 hours, no multiple trauma, no history of stroke and epilepsy, not currently taking sedative drugs and a Brain CT Scan was performed.

The severity of the brain injury was assessed by measuring the level of consciousness using the Glasgow Coma Scale (GCS), then translated into Mild Brain Injury with GCS 13 - 15, Moderate Brain Injury with GCS 9 - 12 and as Severe Brain Injury with GCS 8.

The neuron specific enolase (NSE) assess in the Biomedical Laboratory Faculty of Medicine, Andalas University, using the Elisa technique, using a Kit from The Bioassay Technology Laboratory (BT Lab). This research has also passed the ethical review from the
Research Ethics Commission of the Faculty of Medicine, Andalas University, number: 532/UN.16.2/KEP-FK/2021.

Subjects characteristics are presented in the frequency table and statistical analysis using SPSS 22. Differences in NSE serum levels on the degree of brain injury were analyzed by the Kruskal-Wallis test and differences in NSE serum levels to outcomes were tested by the Mann-Whitney test. The result were significant if the $\mathrm{p}$ value $<0.05$.

\section{Results}

There were 72 patients who included in this study, consisted of 23 mild brain injury, 26 moderate brain injury and 23 severe brain injury. The following are the characteristics of the patients.

Table 1. Basic characteristics of traumatic brain injury patients

\begin{tabular}{lc}
\hline \multicolumn{1}{c}{ Variable } & $\mathrm{N}$ \\
\hline Gender & $52(72.2 \%)$ \\
$\quad$ - Male & $20(27.8 \%)$ \\
$\quad$ - Woman & $36.03(18-60)$ \\
Age (years) & \\
Severitas & $23(31.9)$ \\
$\quad$ - Mild (GCS 13 - 15) & $26(36.1 \%)$ \\
$\quad$ - Moderate (GCS 12-9) & $23(32.0 \%)$ \\
$\quad$ - Severe (GCS 3 - 8) & \\
Outcome & $44(61.1 \%)$ \\
- Good & $28(38.9 \%)$ \\
- Poor & $7,533(3,458-40,171)$ \\
Serum NSE level (ng/ml)
\end{tabular}

Amount of patients with traumatic brain injuries were more affected male than female with a ratio of 2.66 $: 1$, with an average age of 30 years and an average NSE level $7.533 \mathrm{ng} / \mathrm{ml}$. In this study, the average serum
NSE levels in severe brain trauma patients were much higher when compared to mild and moderate brain injury, as shown in the table 1.

Table 2. Relationship of NSE serum levels with Severity of traumatic brain injury

\begin{tabular}{|c|c|c|c|c|}
\hline \multirow{2}{*}{ Variable } & \multicolumn{3}{|c|}{ Severitas } & \multirow{2}{*}{$\mathrm{p}$} \\
\hline & $\begin{array}{l}\text { Mild Brain } \\
\text { Injury }\end{array}$ & $\begin{array}{c}\text { Moderate Brain } \\
\text { Injury }\end{array}$ & $\begin{array}{l}\text { Severe Brain } \\
\text { Injury }\end{array}$ & \\
\hline $\begin{array}{l}\text { Serum NSE level, ng/ml } \\
\text { Median (Min-Max) }\end{array}$ & $\begin{array}{c}6.69 \\
(3.46-8.73)\end{array}$ & $\begin{array}{c}7.44 \\
(5.74-28.41)\end{array}$ & $\begin{array}{c}10.60 \\
(4.25-40.17)\end{array}$ & 0.005 \\
\hline
\end{tabular}

*: Kruskal Wallis 


\begin{tabular}{lc}
\hline & $\mathrm{p}$ \\
\hline CKR vs CKS group & 0.148 \\
CKS vs CKB group & 0.002 \\
CKR vs CKB group & 0.030 \\
\hline
\end{tabular}

Significant differences were obtained in serum levels between mild brain injury and severe brain injury groups and between moderate brain injury and severe brain injury, but not for the mild brain injury and moderate brain injury groups. In this study, outcomes were assessed 6 weeks after brain injury using the Glasgow Outcome Scale (GOS). The results of the GOS assessment are grouped into two categories, namely good outcome with GOS value is 4 and 5 , poor outcome with GOS value is 1,2 and 3 .

Table 3. Relationship between serum NSE levels and outcome of traumatic brain injury

\begin{tabular}{|c|c|c|c|}
\hline \multirow[b]{2}{*}{ Variable } & \multicolumn{2}{|c|}{ Outcome } & \multirow[b]{2}{*}{$\mathrm{p}$} \\
\hline & Good & Poor & \\
\hline $\begin{array}{c}\text { Serum NSE level, ng/ml, } \\
\text { Median (Min-Max) }\end{array}$ & $\begin{array}{r}7.22 \\
(3.46-40.01)\end{array}$ & $\begin{array}{c}7.87 \\
(4,25-40,17)\end{array}$ & $0.045^{*}$ \\
\hline
\end{tabular}

*Mann-Whitney test

There were significant differences in NSE serum levels between the good and poor outcome groups. High NSE serum levels in the acute phase

\section{Discussion}

During the study period, there were 72 patients with traumatic brain injury (TBI) consisting of 23 people with mild brain injury with a glasgow coma scale (GCS) of 13-15, 26 people with moderate brain injury with a GCS value of 9-12 and 23 people with severe brain injury with GCS score 8 . There are more males than females with a ratio of $2.7: 1$.

Almost all studies on traumatic brain injuries report that there are more male sufferers than women, this is because traumatic brain injuries are mostly caused by motor vehicle accidents, where the perpetrators of motorbikes and cars are mostly male. The average age of TBI sufferers in this study was 36 years with a range of 18-60 years.

Outcome was assessed at 6 weeks post-brain injury using the Glasgow Outcome Scale (GOS). The results of the outcome assessment were classified as good if the GOS score was 4 and 5 and were classified as poor if the GOS score was 1 to 3 .

NSE is the main protein in the brain, constituting are associated with poor outcomes at 6 weeks after injury.

between $0.4 \%$ and $2.2 \%$ of the total protein and from research it is known that NSE reaches the peripheral blood via the lymphatic system. NSE is a $78 \mathrm{kDa}$ dimeric enzyme with a half-life of about 24 hours. It is an isoenzyme of enolase. dominantly found mostly in neuronal ( $\mathrm{\gamma} \gamma$-dimer) and peripheral neuroendocrine networks (mixture of and units) ${ }^{9,10,11}$, which play an important role in the glycolytic pathway. Under normal conditions, NSE is not excreted into the extracellular space, however, during cellular injury or death, NSE can be leaked into the extracellular space and respond in NSE to neuronal tissue damage.

There were significant differences in NSE levels in mild brain injury, moderate brain injury and severe brain injury, where the more severe the level of injury, the higher NSE levels were found (table 2). The same result was also found by Mercier ${ }^{12}$. There was no association between higher serum NSE levels and Post Concussion Syndrome, but a positive association was found between higher NSE levels 
and persistent headaches at 6 months after injury, as reported by de Kruijk JR et al ${ }^{13}$.

In this study, it was also found that there was a significant relationship between NSE levels 48 hours after brain injury with good and poor outcome 6 weeks after injury (Table 3). High levels of NSE in the acute phase of injury are associated with poor outcomes at 6 weeks after injury. Recent studies have shown that elevated levels of NSE in serum and cerebrospinal fluid have been shown to be associated with death and permanent neurological disability in patients with moderate or severe TBI ${ }^{12}$. It has been suggested long before that NSE might be used as a prognostic marker in mild brain injury, which at first glance seems normal, but has later caused problems in the cognitive field ${ }^{14,15}$. A large cohort study reported a significant association between higher serum NSE levels and decreased performance on standardized physical assessments performed 6 weeks after a mild traumatic brain injury (TBI). This relationship became stronger after multivariate analysis ${ }^{16}$.

This study has a limitation in not detailing the various disorders that are still felt at follow-up at 6 weeks after the brain injury such as headaches and various disorders in the cognitive domain, because it only assesses outcomes based on the GOS scale. We know that the GOS scale only assesses the dependency and physical disability aspects of a person after a brain injury.

\section{Conclusion}

High NSE serum levels in the acute phase of traumatic brain injury were associated with the severity of brain injury and poor outcome in 6 weeks after.

\section{References}

1. Hyder AA, Wunderlich CA, Puvanachandra P, Gururaj G, Kobusingye OC. The impact of traumatic brain injuries: a global perspective. NeuroRehabilitation. 2007; 22(5): 341-53.

2. Gustavsson A, Svensson M, Jacobi F, Allgulander C, Alonso J, Beghi E, et al. Cost of disorders of the brain in Europe 2010. Eur Neuropsychopharmacol. 2011; 21(10): 71879.

3. Roozenbeek B, Maas AI, Menon DK. Changing patterns in the epidemiology of traumatic brain injury. Nat Rev Neurol. 2013; 9(4): 231-6.

4. Signorini DF, Andrews PJ, Jones PA, Wardlaw JM, Miller JD. Predicting survival using simple clinical variables: a case study in traumatic brain injury. $\mathrm{J}$ Neurol Neurosurg Psychiatry. 1999; 66: 20-5.

5. McHugh GS, Engel DC, Butcher I, Steyerberg EW, Lu J, Mushkudiani N, et al. Prognostic value of secondary insults in traumatic brain injury: results from the IMPACT study. J Neurotrauma. 2007; 24(2): 287-93.

6. ChNSEut RM, Marshall LF, Klauber MR, Blunt BA, Baldwin N, Eisenberg HM, et al. The role of secondary brain injury in determining outcome from severe head injury. J Trauma. 1993; 34(2): 216-22.

7. Hemingway H, Croft P, Perel P, Hayden JA, Abrams K, Timmis A, et al. Prognosis research strategy (PROGRESS) 1: a framework for researching clinical outcomes. BMJ. 2013; 346: 5595.

8. Strathmann FG, Schulte S, Goerl K, Petron DJ. Blood-based biomarkers for traumatic brain injury: evaluation of research approaches, available methods and potential utility from the clinician and clinical laboratory perspectives. Clin Biochem. 2014; 47: 876-88.

9. Isgro MA, Bottoni $\mathrm{P}$, Scatena R. Neuronspecific enolase as a biomarker: biochemical 
and clinical aspects. Adv Exp Med Biol. 2015; 867: 125-43.

10. Skogseid IM, Nordby HK, Urdal P, Paus E, Lilleaas F. Increased serum creatine kinase $\mathrm{bb}$ and neuron specific enolase following head injury indicates brain damage. Acta Neurochir (Wien). 1992; 115(3-4): 106-11. doi:10.1007 / BF01406367.

11. Scolletta S, Donadello K, Santonocito C, Franchi F, Taccone FS. Biomarkers as predictors of outcome after cardiac arrest. Expert Rev Clin Pharmacol. 2012; 5(6): 68799. doi:10.1586/ecp.12.64.

12. Mercier E, Boutin A, Shemilt M, Lauzier F, Zarychanski R, Fergusson DA, Moore L, McIntyre A, Archambault P, Légaré F, et al. Predictive value of neuron-specific enolase for prognosis in patients with moderate or severe traumatic brain injury: A systematic review and meta-analysis. Cmaj Open. 2016; 4(3): $\quad 371-\quad 382$. doi: $10.9778 /$ cmajo.20150061

13. de Kruijk JR, Leffers P, Menheere PPCA, Meerhoff S, Rutten J, Twijnstra A. Prediction of post-traumatic complaints after mild traumatic brain injury: early symptoms and biochemical markers. J Neurol Neurosurg Psychiatry. 2002; 73(6): 727-32. doi:10.1136/ jnnp.73.6.727.

14. Woertgen C, Rothoerl RD, Holzschuh M, Metz C, Brawanski A. Comparison of serial s100 and nse serum measurements after severe head injury. Acta Neurochir (Wien). 1997; 139(12): 1161-65. doi:10.1007/BF01410977.

15. Herrmann M, Jost S, Kutz S, Ebert AD, Kratz T, Wunderlich MT, Synowitz H. Temporal profile of release of neurobiochemical markers of brain damage after traumatic brain injury is associated with intracranial pathology as demonstrated in cranial computerized tomography. J Neurotrauma. 2000; 17(2): 113-22. doi:10.1089/ neu.2000.17.113

16. Topolovec-Vranic J, Pollmann-Mudryj MA, Ouchterlony D, Klein D, Spence J, Romaschin A, Rhind S, Tien HC, Baker AJ. The value of serum biomarkers in prediction models of outcome after mild traumatic brain injury. J Trauma-Injury Infect Crit Care. 2011; 71: 478-486. doi:10.1097/TA.0b013e318232fa70 